\title{
Impact of Social and Institutional Factors on the Uptake of Conservation Agriculture: A Case of Zambia and Zimbabwe
}

\author{
Putso Nyathi ${ }^{1}$, Thinah Moyo ${ }^{2}$, Helena Posthumus ${ }^{3}$ \& Joe Stevens ${ }^{1}$ \\ ${ }^{1}$ University of Pretoria, Department of Agricultural Economics, Extension and Rural Development, Pretoria, \\ South Africa \\ ${ }^{2}$ National University of Science and Technology, Department of Agriculture and Natural Resources Sciences, \\ Windhoek, Namibia \\ ${ }^{3}$ KIT Royal Tropical Institute, Amsterdam, Netherlands \\ Correspondence: Putso Nyathi, United Nations Office in Nairobi, Gigiri, Nairobi, Kenya. Tel: 254-703-142-506. \\ E-mail: nyathip@gmail.com
}

Received: December 29, 2019 Accepted: January 24, 2020 Online Published: January 26, 2020

doi:10.5539/sar.v9n1p67

URL: https://doi.org/10.5539/sar.v9n1p67

\begin{abstract}
Conservation agriculture (CA) involves the practice of three interlinked principles of minimum soil disturbance, a permanent soil cover and crop rotation. Despite the many stated benefits of the technology, its uptake in Africa has been slow. This study applies the theory of planned behaviour to investigate the attitudes, the role of the social system (social influence, by-laws and customs) and the institutional environment in the decision to practice CA principles and on the area under CA in Choma, Zambia and Nkayi, Zimbabwe. The study finds differing attitudes between districts towards CA outcomes. Local by-laws have a positive correlation with the practice of minimum soil disturbance but negative correlations with the practice of soil cover and crop rotation. Social influence and customs have significant relationships with the area under CA. Institutional support is perceived to be necessary for the practice of minimum soil disturbance but not so for the practice of crop rotation or on the area under CA. We conclude that the attitudes towards CA depend on the performance of the CA options promoted to farmers while the effects of the social system components and institutional factors on the uptake of CA depends on how the particular CA principle fits into the social and institutional environment in which it is promoted. We recommend agriculture extension services and policymakers to pay more attention to these issues in the promotion of CA.
\end{abstract}

Keywords: conservation agriculture, decision-making, extension, smallholder farmers, social system, theory of planned behaviour

\section{Introduction}

With the current global challenges of attaining food security while protecting the environment, conservation agriculture (CA) is perceived as one technology that can contribute towards achieving both objectives (Corbeels et al., 2014). In sub-Saharan Africa, CA has been promoted to address the challenges of land degradation and poor crop yields for smallholder farmers (Anderson \& D’Souza, 2014). In Zimbabwe for example, the average maize yield for smallholder farmers is estimated to be less than one ton per hectare (Marongwe et al., 2011) while in Zambia, crop production is largely vulnerable to climatic conditions (Shula et al., 2012).

$\mathrm{CA}$ is a resource-saving crop production system that strives to achieve acceptable profits, high and sustained production levels while concurrently conserving the environment (Food and Agriculture Organization [FAO], 2010). This is achieved through improved management and application of three key principles, namely; minimum soil disturbance, permanent soil cover and diversified crop associations or rotations. However, despite more than a decade of promotion in southern Africa, the adoption of CA in the smallholder sector is still minimal (Kassam, 2014). Zimbabwe and Zambia are some of the leading countries in Africa in terms of area put under CA, with about 316000 and 100000 ha put under CA in Zambia and Zimbabwe respectively in 2015/2016 (Kassam, Friedrich \& Derpsch, 2018). However, the area under CA is still very low in Africa compared to the rest of the world. Africa has about $1.1 \%$ of the continent's total arable land under CA, while South America has about $63 \%$ of the region's cropland under CA (Kassam et al., 2018). 
Several studies have sought to identify the reasons for the low uptake of CA in Africa, including in Zambia and Zimbabwe. Adoption studies have identified biophysical factors (agro-ecological region), household characteristics (Mazvimavi \& Twomlow, 2009; Arsalan, McCarthy, Leslie, Asfaw, \& Cattaneo, 2013; Ngwira, Johansen, Aune, Mekuria, \& Thiefelder, 2014; Pedzisa, Rugube, Winter-Nelson, Baylis, \& Mazvimavi, 2015), institutional factors such as access to credit, markets and extension services (Nyanga, 2012) and the ease of application (Prager \& Posthumus, 2010) to affect adoption. The studies report that CA is more likely to be adopted in high rainfall areas in Zimbabwe (Mazvimavi \& Twomlow, 2009) and in low rainfall areas in Zambia (Nyanga, 2012). Access to extension services and markets were found to positively correlate with CA adoption. The effect of access to credit and household characteristics such as age, education level and farm size on CA adoption were mixed.

Very few studies have examined the role of social factors in the uptake of CA (Knowler \& Bradshaw, 2007). Studies that explored the effects of social factors are limited to the role of social networks in explaining adoption (Isham, 2000; Katungi, 2006; Mashavave, Mapfumo, Mtambanegwe, Gwandu, \& Siziba, 2013) yet social networks only form part of the social system. The social system includes social customs, rules, the social structure, the individuals and social networks (Rogers, 2003). These factors play a role in the dissemination and adoption of technologies through informal sharing of information (Shaw, 1987; Pannell et al., 2006) and the pressure they exert on an individual to conform to certain socially expected norms (Ajzen \& Fishbein, 1980; Kate, Haverkamp, Mahmood, \& Feldberg, 2010). The other limitation with adoption studies on CA is that they rely on household data models that miss important social, cultural and institutional factors that may influence adoption (Feder, Just, \& Ziberman, 1985; Anderson \& D'Souza, 2014). CA is a knowledge-intensive technology and its adoption and practice presents a shift in the farming system and a reallocation of resources (Giller, Witter, Corbeels, \& Tittonell, 2009).

This study fills the gap on CA adoption by exploring the attitudes of CA adopters towards CA; and goes beyond exploring the role of social networks by including more social system components (such as peers, local leaders, spouses, groups, by laws and customs) in explaining CA adoption and the area under CA. The study also explores the importance of access to institutional support in the form of credit, markets, implements and extension services on the uptake of CA principles and on the area under CA. The methodology used in the research uses farmer perceptions rather than relying on household characteristics to explain behaviour.

\section{Materials and Methods}

\subsection{Conceptual Framework}

The conceptual framework for the study is based on the Theory of Planned Behaviour (TPB), originally developed by Ajzen (1991) as a framework to analyse decision-making (Fishbein \& Ajzen, 2010). In the TPB, intention is perceived as a predictor for a specific behaviour, and is determined by three central constructs, attitude, subjective norms and perceived behavioural control (Ajzen, 1991). An individual's decision is influenced by personal factors termed attitudes and the person's perception of social expectations to a certain behaviour, which are called 'subjective norms'. A third component of the theory is the perceived capability (having the skills and knowledge) and perceived conduciveness of the environment for change behaviour, referred to as Perceived Behaviour Control (PBC). Together, attitude, subjective norm and perceived behaviour control lead to a positive or negative intention to apply or adopt certain practices.

The framework is modified by directly linking attitudes, subjective norms and PBC to adoption. In our framework, beliefs about the performance of a technology, subjective norms and perceived capability are mediated by background factors (household characteristics, learning environment and farming goals) as shown in Figure 1. Personal characteristics mediate attitudes, while the social context (gender, social customs etc.) mediate normative beliefs, and the learning process and farming goals mediate the $\mathrm{PBC}$, which then impact on the decision to adopt or not adopt CA.

The assumptions made in the framework are that:

1. Beliefs about expected outcomes (good or bad outcome beliefs), also referred to as attitude towards CA, influence the actual adoption of CA practices.

2. Social influence, measured through beliefs that influential individuals within the social system expect a certain behaviour, will influence adoption.

3. In addition to social influence from individuals, the perceived influence of by-laws and customs on the practice of CA principles is assessed.

4. The PBC, measured as the individual's perceived need/importance of the institutional environment, will 
affect CA adoption.

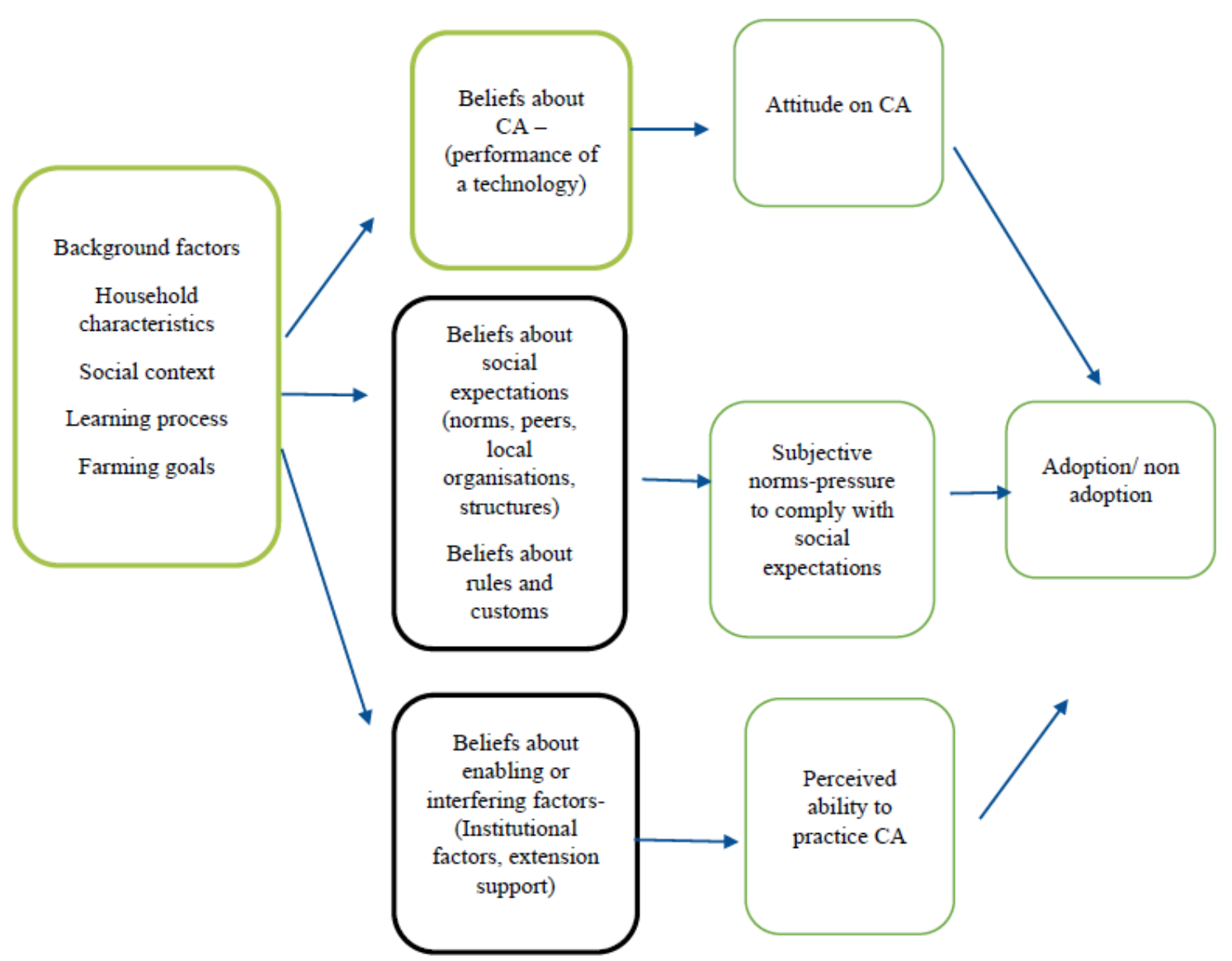

Figure 1. Conceptual framework, adapted from Ajzen, (1991)

\subsection{Study Sites}

The study was conducted in Choma, Zambia and Nkayi, Zimbabwe where previous studies have shown variations between the two countries in the influence of certain factors on CA adoption. In Zambia, farmers in low rainfall areas were more likely to adopt CA (Arsalan et al., 2013); yet in Zimbabwe, CA was most likely to be adopted in high rainfall areas (Pedzisa et al., 2015). Access to credit was not reported as a driver of adoption in Zambia (Nyanga, 2012), yet Mazvimavi and Twomlow (2009) argued that access to credit stimulated adoption in Zimbabwe.

Choma is situated in the southern province of Zambia ( $16^{\circ} 48^{\prime} 59.99^{\prime \prime} \mathrm{S}: 26^{\circ} 58^{\prime} 17.99 "$ E) and falls under agro-ecological region IIa, which is classified as semi-arid, receiving between 700 and $1000 \mathrm{~mm}$ of rainfall per annum. The area experiences a unimodal rainfall pattern which falls from December to March and a dry season from April/ May to October/November (Baudron, Mwanza, Triomphe, \& Bwalya, 2007). The region has relatively fertile soils, which are predominantly sandy and clay loams. The farming system is maize-mixed and small livestock such as goats and sheep play a crucial role in addressing immediate family needs (ibid). Farm size averages one to five hectares, which is typical of smallholder farming (Livingston, Schonberger, \& Delaney, 2011). The major crops grown are maize (Zea mays L), cotton (Gossypium herbaceum L), groundnut (Arachis hypogea, L) and cowpea (Vigna unguiculata (L.) Walp. The conventional method of land preparation is the use of the ox-drawn plough and weed management is also done by ox-drawn cultivator. Land is communally owned and there is free grazing in the dry season. Most families are male-headed although a significant number of female and child-headed families are present due to the HIV/AIDs pandemic (ibid).

Nkayi district is located in northwestern Zimbabwe in Matabeleland North province (19 $00^{\circ} 0.00^{\prime \prime} \mathrm{S}: 28^{\circ} 53^{\prime}$ $59.99 "$ E). The district is a semi-arid area receiving unimodal rainfall of less than $650 \mathrm{~mm}$ per annum (Vincent \& Thomas, 1960). Rain falls between November and April. The district has predominantly Kalahari sands with low nutrients and low water holding capacity (FAO, 2006). Crop production is limited by frequent dry spells, poor 
soil fertility and lack of access to soil fertility amendments such as manure and inorganic fertilisers (Masikati, 2011). Nkayi is conducive for semi-extensive production with crop- and livestock systems being the major farming enterprises. Crops grown in the area include maize (Zea mays L), groundnut (Arachis hypogea L.), bambara groundnut (Vigna subterranea (L.) Verdc.), cowpea (Vigna unguiculat (L.) Walp.), and small grains such as sorghum (Sorghum bicolor (L.) Moench) and pearl millet (Pennisetum glaucum (L.) R.Br.) (Dube, HolmanKeTue, Van Rooyen, \& Rodrguez, 2014). Most farmers in Nkayi use animal-drawn ploughs to prepare their land for farming (Dube te al., 2014). Land is communally owned, and free grazing is the normal practice during the dry season. Food insecurity is a chronic problem in the district with $39 \%$ of the population being food insecure (Zimbabwe Vulnerability Assessment Committee [ZimVac], 2013).

\subsection{Data Collection}

A household survey was conducted with 41 and $61 \mathrm{CA}$ adpoters in Choma and Nkayi, respectively, during the period May to June 2017. The respondents were practising CA farmers who applied at least one principle of CA and were part of CA programs promoted by Brethren in Christ Church (BICC) in Choma and Christian Care (CC) in Nkayi, which are both not-for-profit organisations. BICC promoted CA in Mbabala, Siaskobole and Singani during the period 2013-2017, whilst CC promoted CA in Nkayi during the period 2006-2014. The BICC project was open to those interested in the interventions supported by the project whilst $\mathrm{CC}$ targeted the poor with limited resources and female-headed households. The CA options that were promoted in the two districts are summarized in Table 1.

Table 1. CA options promoted in Choma and Nkayi districts

\begin{tabular}{ll}
\hline Choma CA package & Nkayi CA package \\
\hline Dry season preparation of rip lines using an & $\begin{array}{l}\text { Dig holes called planting basins in the dry season of } 15 \mathrm{~cm} \\
\text { depth, } 15 \mathrm{~cm} \text { width and } 15 \mathrm{~cm} \text { length }\end{array}$ \\
$\begin{array}{l}\text { No burning of crop residues, soil cover with } \\
\text { crop residues or grass }\end{array}$ & $\begin{array}{l}\text { No burning crop residues, complete soil cover with grass or } \\
\text { crop residues }\end{array}$ \\
Crop rotation between cereals and legumes & Crop rotation between cereals and legumes \\
\hline
\end{tabular}
Source: Project documents from implementing organizations (BICC and CC)

In Nkayi, four wards $(14,17,25 \& 29)$ out of twelve wards, where CC operated, were selected through a stratified sampling technique to include traditional communities and different economic environments such as distance to markets. In Choma, random sampling of respondents was done in all the three project areas of Mbabala, Siaskobole and Singani. The three project areas represented different social and economic environments where Siaskobole was the furthest from Choma town and reflected a more traditional community while Mbabala was the nearest to Choma town. The total number of sampled households represented 30\% of CA adopters in the selected areas under the two project interventions, which gave a representative sample of adopters.

Prior to conducting household surveys, interviews were done with key informants through e-mail and face-to-face questionnaires to gather information on customs and influential people in each of the districts. The information from key informants was used to develop a household questionnaire that captured important influential people in communities, institutional factors and customs.

A household questionnaire was designed to collect information on farmers' attitudes towards CA, the role of social system and PBC in influencing adoption of CA principles following guidelines from Fishbein and Ajzen (2010). To determine the attitude of farmers, respondents were asked to respond to a set of questions that reflected possible attitudes towards CA (CA increases yields, CA is not a technology for the poor, practicing CA is not a risk, and CA reduces labour), which were measured on a five-point Likert scale where 'one' represented disagreement and 'five' represented complete agreement. The variable 'social influence' was captured by asking respondents if they perceived local leaders, peers, spouses and farmer groups to have likely or unlikely influenced their adoption of CA. The responses were ranked on a five-point Likert scale. Institutional factors were measured by asking respondents whether they perceived access to credit, extension services, implements and markets, to be necessary in the practice of CA. The responses were also measured on a five point Likert scale. The rankings for each of the Likert questions representing attitude, social influence and $\mathrm{PBC}$ were averaged using Statistical Package for the Social Sciences (SPSS) to get a composite score that represented the specific factor (Fishbein \& Ajzen, 2010). A collection of multiple statements to represent a perception allows inference through parametric analysis such as regression, ANOVA and t-tests (Elaine \& Seaman, 2007). Through 
the same household questionnaire, respondents were also asked how they perceived by-laws and customs to affect the practice of CA. These questions were based on a yes and no answer. In each of the seven sampled areas, one focus group discussion was held to gather more information on the social systems in the areas. Information from focus group discussions was triangulated with findings from the household survey.

\subsection{Data Analysis}

Data was analysed using SPSS Version 25 for descriptive statistics such as chi-square tests and frequencies on the general social systems, demographic characteristics of farmers, institutional environment and adoption figures of the different CA principles. Likert scale data was used to conduct regression analysis to make inferences on CA uptake. The first step in conducting regression tests was to determine the reliability of the Likert scales in representing attitude, social influence and PBC. An internal reliability and consistency of the scales was tested using Cronbach's Alpha coefficient (Cronbach, 1951). Cronbach values greater than 0.7 are considered ideal but could also reflect redundancy of some Likert items (ibid.) while low alpha levels can still be acceptable if they cover meaningful content for a domain and have reasonable uni-dimensionality (Schmitt, 1996). The constructs for social influence and PBC were reasonable, at 0.68 and 0.71 , respectively, indicating that questions meant to measure these constructs were acceptable. However, Cronbach's alpha for attitude was low and hence was not included in the regression. Instead, an analysis of each individual Likert question that represented attitude was done through a Mann-Whitney-U test to compare attitudes between districts. The test was also use to compare social influence and PBC between the two districts. The Mann-Whitney U test has similar predictive power like the t-test to compare two groups even with small sample sizes and is especially applicable for single Likert scale statements (De Winter \& Dodou, 2010).

A binomial logistic regression analysis was conducted to investigate the effects of social influence, by-laws, norms and institutional factors in the adoption of CA principles. Binomial logistic regression estimates the probability of an event (in this case, adoption of CA principles) occurring. If the estimated probability of CA adoption occurring is greater than or equal to 0.5, the event is classified as occurring (e.g., CA principles adopted). If the probability is less than 0.5 , the event is classified as adoption not occurring. The category prediction percentage analysis (predictive power of the model) was done to explain the percentage accuracy in classification (PAC), which reflects the percentage of cases that were correctly classified as "non" adoption of CA principles, with the independent variables added. The higher the percentage, the better fit the model to the data because the addition of explanatory variables increases the percentage of correct classification significantly if the model is good.

A binary logistic regression predicts the probability that an observation falls into one of two categories of the dichotomous dependent variable (adoption of CA principles, where Yes $=1$, or $0=$ Otherwise), based on independent variables Social Influence, By-laws, Customs and PBC. By applying logistic regression, CA adoption was measured as a binary variable and the explanatory variables were either binary too (i.e. By-laws, Customs) or ordinal (i.e. Social influence, Perceived Behaviour Control).

Equation (1) shows a mathematical representation of the binomial regression model derived from O'Connell, (2011).

$$
A d_{i}=\alpha+\beta S I_{i}+\beta B L_{i}+\beta C_{i}+\beta P B C_{i}+\varepsilon
$$

where $A d$ represents adoption of CA principles $i, \alpha$ is the constant, $S I$ is the social influence, $B L$ is by laws, $C$ is Customs and $P B C$ is Perceived Behaviour Control on the adoption of CA principles $i, \beta$ is the regression coefficient and $\varepsilon$ is the error term. The analysis focused on all three CA principles as dependent variables.

Ordinary least square regressions were done to investigate the effects of social and institutional factors on the total area under to CA. The study used total area under CA instead of the proportion of area under CA because total area under CA has been used before to measure adoption (Nyanga, 2012) and because the proportion of land allocated to new technologies is not limited by farm size (Wall, 2007; Arsalan, et al., 2013). Based on this, it was assumed that the area under CA would be influenced by the predictor variables for CA adoption.

\section{Results}

\subsection{Socio-economic Characteristics of Respondents}

A total of $102 \mathrm{CA}$ farmers were interviewed and of these 57 percent of the respondents were female. Female representation was however, lower in Choma (37\%) than in Nkayi (72\%). Table 2 provides a summary of the socio-economic characteristics of the respondents. The average age was 44 years in Choma and 54 years in Nkayi. The average number of years of schooling were seven years for each district. The average household sizes were similar with seven people in Choma and eight people in Nkayi. Household assets and incomes varied 
slightly between districts. On average, each farmer owned five cattle in Choma and seven in Nkayi. Respondents in Choma had on average five hectares of land for farming whilst Nkayi had on average two hectares. Farmers were cultivating 40 to $60 \%$ of their fields as seen by the total area allocated to CA and conventional fields. CA was practiced on nine percent in Choma and 15 percent of total arable land in Nkayi. Non-farm income from activities such as petty trade, and brick laying contributed less income per year in Choma (US\$150 (Note 1)) than in Nkayi (US\$500 (Note 2)). There was little variation in income from on-farm production (livestock and crop production) between the two districts although Choma had a higher total farm income of US $\$ 387$ per year than in Nkayi district with US $\$ 300$ per year. Yield level comparison between the two districts reflected higher productivity in Choma for both conventional $\left(1424 \mathrm{~kg} \mathrm{ha}^{-1}\right)$ and CA $\left(1550 \mathrm{~kg} \mathrm{ha}^{-1}\right)$ compared with a conventional yield of $704 \mathrm{~kg} \mathrm{ha}^{-1}$ and CA yield of $880 \mathrm{~kg} \mathrm{ha}^{-1}$ in Nkayi. Choma respondents had relatively closer input markets $(38.6 \mathrm{~km})$ than respondents in Nkayi $(57 \mathrm{~km})$. Access to extension services was high in both districts as seen by the percentage of farmers that meet an extension agent at least monthly. Farmers in Choma were mostly getting extension support from NGOs (95\%) whilst in Choma they were getting support from both government (44\%) and NGOs (56\%). Forty eight percent of farmers in Choma had accessed credit at some point compared with only $20 \%$ of farmers in Nkayi. Credit sources were mainly village savings (18\%), neighbours (3.5\%), microfinance institutions (9\%) and farmer organizations (8\%).

Table 2. Socio-economic characteristics of CA adopters in Choma and Nkayi districts

\begin{tabular}{lll}
\hline Household characteristic & $\begin{array}{l}\text { Choma } \\
(\mathrm{n}=41)\end{array}$ & $\begin{array}{l}\text { Nkayi } \\
(\mathrm{n}=61)\end{array}$ \\
\hline Age of respondent (years) & $43(13.471)$ & $54(11.135)$ \\
Years of schooling & $6.6(2.597)$ & $6.9(2.893)$ \\
Mean number of people in household & $7.5(3.763))$ & $8.2(2.982)$ \\
Number of people who contribute to full time labour & $3.4(2.480)$ & $2.8(1.463)$ \\
Area of land belonging to you (hectares) & $4.9(7.616)$ & $2.3(1.206)$ \\
Total area cultivated (conventional) & $1.5(0.980)$ & $1(.786)$ \\
Area under CA (hectares) & $0.44(0.36)$ & $0.36(0.42)$ \\
Cattle ownership (number) & $5(6.1)$ & $7(7.1)$ \\
Annual income from non-farm activities (US\$) & $145.1(216)$ & $300.18(502)$ \\
Annual on-farm income (US\$) & $387.5(601.7)$ & $304(465)$ \\
Yield maize conventional (kg/ha) & $1424(898)$ & $744(800)$ \\
Yield maize for CA (kg/ha) & $1550(1112)$ & $886(1174)$ \\
Distance to input market (km) & $38.6(7.4)$ & $57(80)$ \\
$\%$ that meet extension agent at least once a month & 95 & 81 \\
$\%$ that accessed credit & 48 & 20 \\
\hline
\end{tabular}

Notes: Figures in parenthesis are standard deviations

Source: Survey data

\subsection{Social Customs and By-laws in the Study Districts}

To understand how customs and by-laws influence adoption Table 3 provides a list of customs and by-laws that were perceived to influence farming activities in the two districts. Customs refer to the way things are done in a particular community while by-laws refer to regulations that govern communities (Rogers, 1992). The study focused more on customs and by-laws that were related to farming activities. A Pearson chi square test of independence showed significant differences in customs between districts $\left(X^{2}=25.95, \mathrm{df}=4, \mathrm{p}=0.000\right)$ but no significant difference in by-laws. In Nkayi, the major customs highlighted were sacred days that prohibited people from entering their fields (either after a heavy storm or when there is a funeral or when there is a full moon and on a day that a community has set aside as a resting day). Such customs were perceived to delay timely fieldwork especially if there are many sacred days observed in a season. In Choma, the main customs highlighted as influencing farming practices were prohibition of fencing of fields and the custom that prohibits women from owning land. Prohibition of fencing keeps people from exercising exclusive control of their fields and the decisions they can make about field activities like practicing mulching. The major by-laws that were perceived to affect farming activities were communal grazing and prohibition of entry to fields in the dry season. The local rules were said to affect crop residue retention in CA (84\% respondents in both Nkayi and Choma) and delay CA land preparation (6\% Nkayi and 11\% Choma). 
Table 3. Customs and by-laws in Choma and Nkayi districts

\begin{tabular}{lll} 
& & Nkayi \\
& $\mathrm{n}=88$ responses & $\begin{array}{l}\text { Choma } \\
\mathrm{n}=40 \text { responses }\end{array}$ \\
\hline Customs & 75 & 0 \\
Respecting sacred days \% & 13 & 0 \\
Rain making ceremonies \% & 0 & 38 \\
No fencing to traditional land \% & 0 & 24 \\
Women do not own land \% & 10 & 2.2 \\
Protect grazing areas & & 18 \\
By laws & 5.1 & 18 \\
No burning bushes \% & 0 & 87 \\
No selling traditional land \% & 61 & 8 \\
Communal grazing in the dry season \% & 3.4 & \\
No entry into field in dry season \% & & \\
\hline
\end{tabular}

Source: Survey data

\subsection{Adoption of CA Principles}

Respondents were asked to indicate the CA principles they had practiced in the 2016/17 cropping season. Figure 2 provides a summary of adoption of the three principles of CA in the two districts. Minimum soil disturbance (MSD) was the most adopted principle in both Choma and Nkayi. Crop rotation (of cereals with legumes) and soil cover were more adopted in Nkayi compared to Choma. The difference is adoption levels could because farmers in Nkayi had practiced CA for longer ( 9 years) than Choma (5 years).

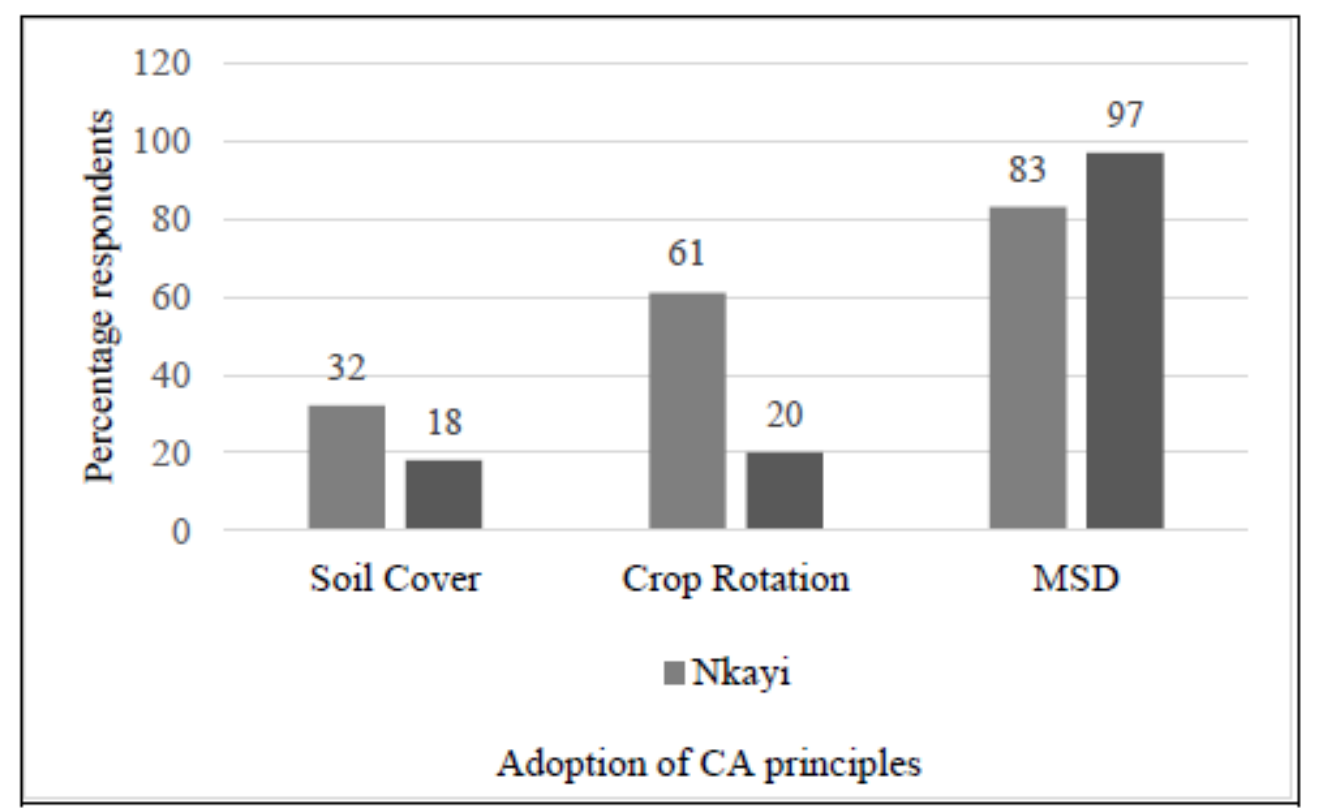

Figure 2. Adoption of CA principles by district

Source: Survey data

\subsection{Attitude towards $C A$}

Responses to questions that measured attitude reflected generally positive attitudes towards CA except on the statement that CA saves labour. Ninety percent of respondents agreed with the statement that CA increased yield, $32 \%$ agreed with the statement that CA saved labour, 72\% believed CA was not a technology for the poor and 74\% believed that practicing $\mathrm{CA}$ was not taking a risk. Table 4 shows a comparison of attitude statements between districts using a Mann-Whitney $\mathrm{U}$ test. The test found a significant difference between statements on CA increased yield (at 1\% level of significance), CA saved labour and CA is not taking a risk (both at $5 \%$ level of significance). 
Table 4. Comparison of attitudes between districts using a Mann-Whitney U test

\begin{tabular}{lllll}
\hline Attitude statement & District & $\mathrm{N}$ & Mean Rank & $p$-value \\
\hline CA increases yield & Choma & 41 & 41.32 & $0.000^{* * *}$ \\
& Nkayi & 61 & 58.34 & \\
CA requires less labour & Choma & 41 & 58.57 & $0.035^{* *}$ \\
& Nkayi & 61 & 46.75 & \\
Practicing CA is not a risk & Choma & 41 & 58.72 & $0.030^{* *}$ \\
& Nkayi & 61 & 46.65 & \\
CA is not for the poor & Choma & 41 & 38.13 & 0.610 \\
& Nkayi & 61 & 34.59 & \\
\hline
\end{tabular}

Notes: ${ }^{* *}$ means significant at $5 \%,{ }^{* * *}$ means significant at $1 \%$ significance levels

Source: Survey data

\subsection{The Role of the Social System in the Adoption of CA Principles}

\subsubsection{Model Prediction Goodness of Fit}

Classification results for evaluating the three logistic regression models showed the model for MSD having the highest prediction percentage $(87.9 \%)$ of cases followed by the soil cover model $(72.7 \%)$ and the model for crop rotation having the least prediction percentage $(55.6 \%)$. These results indicate the goodness of fit for the logistic models. In this case at greater than $70 \%$ correct classification, models for MSD and soil cover had better predictive power than that for crop rotation.

\subsubsection{The Role of Social Influence, By-laws, Customs and PBC on Adoption}

A summary of the findings of the relationship between social system influence (social influence, by-laws, customs), and institutional factors (PBC) on adoption of CA principles and area under CA is shown in Table 5. The results provide both positive and negative relationships between the study variables. Social influence had a significant and positive relationship with the area under CA $(p<0.01)$ and mixed, but not statistically significant correlation with the adoption of CA principles. The by-laws had a significant and positive relationship with the adoption of MSD $(p<0.01)$ and a significant negative relationship with the adoption of soil cover $(p<0.10)$ and crop rotation $(p<0.10)$. The main by-laws in the two districts allowed free grazing during the dry season and prohibited farmers to enter their fields during the same period. Customs such as the observance of sacred days, protecting grazing areas and no fencing of land had a significantly negative effect on the area under CA $(p<0.05)$ and had a negative relationship with the adoption of the three CA principles although not statistically significant. The PBC, which measured the perceived importance of institutional factors in practicing $\mathrm{CA}$, was significantly negative for the practice of MSD $(p<0.01)$ and significantly positive for the practice of crop rotation $(p<0.05)$ and area under CA $(p<0.05)$.

Table 5. Relationship between social system and institutional factors with the adoption of CA principles and area under $\mathrm{CA}$

\begin{tabular}{lllll}
\hline Influencing factor & Minimum soil disturbance & Soil cover & Crop rotation & Area under CA \\
\hline & $\mathrm{b} / \mathrm{se}$ & $\mathrm{b} / \mathrm{se}$ & $\mathrm{b} / \mathrm{se}$ & $\mathrm{b} / \mathrm{se}$ \\
\hline PBC (institutional factors) & $-0.576^{* * *}(0.212)$ & $0.284(0.211)$ & $0.536^{* *}(0.215)$ & $0.431^{* *}(0.186)$ \\
Social influence & $0.156(0.131)$ & $0.166(0.137)$ & $-0.083(0.126)$ & $0.347^{* * * *}(0.120)$ \\
By-laws & $0.880^{* * * *}(0.324)$ & $-0.522^{*}(0.303)$ & $-0.528^{*}(0.295)$ & $0.039(0.284)$ \\
Customs & $-0.017(0.284)$ & $-0.129(0.289)$ & $-0.089(0.277)$ & $-0.268^{* *}(0.132)$ \\
Constant & $0.992(0.948)$ & $-1.923^{*}(1.005)$ & $-1.758^{*}(0.982)$ & $-0.672(0.831)$ \\
$\mathrm{N}$ & 102 & 102 & 102 & 100 \\
$p$-value & 0.008 & 0.255 & 0.073 & 0.002 \\
Ll & -60.921 & -57.279 & -65.453 & -158.703 \\
\hline Notes ${ }^{*}$ means significant at & $10 \%{ }^{* *}$ means significant at $5 \%,{ }^{* * *}$ means significant at $1 \%$ significance levels,
\end{tabular}

Figures in parentheses are the standard errors, $b=$ beta coefficient, se $=$ the standard error

Source: Survey data 


\subsection{Comparison of Social Influence and PBC between Choma and Nkayi}

Table 6 shows a further comparison of perceptions on social influence and institutional environment between districts using a Mann-Whitney $\mathrm{U}$ test. The test found a significant difference in social influence between Choma and Nkayi $(p=0.01)$ but no significant difference in perceived behaviour control $(p=0.5)$.

Table 6. Comparison of perceptions on social influence and PBC on adoption between Choma and Nkayi

\begin{tabular}{llll}
\hline Variable & District & Mean rank & $p$-values \\
\hline Social influence & Choma Nkayi & 60 & \\
& & 46 & $0.01^{* *}$ \\
Perceived Behaviour Control & Choma Nkayi & 47 & \\
& & 51 & 0.5 \\
\hline
\end{tabular}

Notes: ${ }^{* * *}$ means significant at $5 \%$ significance level.

Source: Survey data $(\mathrm{n}=102)$

\section{Discussion}

The objectives of the study were to explore the attitudes of CA farmers and the role of the social system and institutional factors in the adoption of CA principles and on the area under CA. A discussion of the findings is as follows:

\subsection{Attitude towards CA:}

Findings reveal differences in attitudes on specific aspects of CA between districts. This may be a reflection of the performance of CA in addressing farmers' constraints such as yield and labour in a particular context. The perceived benefits and constraints may be related to the CA package that was promoted in the particular district. In Choma, farmers were more positive about $\mathrm{CA}$ being labour-saving due to probably the use of the ox-drawn ripper, which was reported to be labour saving already by Nyanga (2012). In Nkayi, farmers had a more positive attitude that CA increases yields due to the use of planting basins, which are reported to result in higher yields than ripped fields (Nyamangara et al., 2014) even though there was not much difference in yield for CA between the two districts for the 2016/17 cropping season. Such attitudes have the potential to influence CA adoption. Pedzisa et al. (2015) and Wall (2007) found adoption of CA to be related with perceived performance and yield benefits derived from the technology.

\subsection{The Role of the Social System (Social Influence, by laws, customs) in the adoption of CA:}

The findings suggest that each of the CA principles poses different constraints and opportunities to farmers. The negative relationship between the by-laws with soil cover complements other findings that report that CA conflicts with the farming system (Giller et al., 2011), and that farmers prefer to feed livestock with crop residues (Mazvimavi \& Twomlow, 2009). Our findings reflect that the pressure to conform to communal by laws may limit farmers to practice soil cover. In Choma for example, focus group discussions with farmers indicated that it was not socially acceptable in a community to fence fields as one could be excluding themselves from the community. In Nkayi, farmers lamented communal by laws that protected grazing areas as they prohibited CA farmers from cutting grass for use as soil cover from areas reserved for livestock grazing.

The correlation between the by-laws and the adoption of minimum soil disturbance was expected to be negative because for farmers to apply the MSD principle, they are expected to prepare their land in the dry season (Twomlow, Urolov, Jenrich, \& Oldrieve, 2008; Nyanga, 2012) a time when livestock are grazing freely. Focus group discussions in Nkayi, revealed that when farmers maintained the same planting stations every year, land preparation became easier over time and most of them were no longer starting land preparation early in the dry season. In Choma, farmers reported that ripping was normally done early into the cropping season when free grazing is reduced. Nyanga (2012) also reports similar findings in Zambia were farmers avoided ripping during the dry season as the soil is hard and livestock are weak at that time. It is however surprising that by-laws were negatively correlated with the adoption of crop rotation as the listed by-laws do not necessarily show any connection with crop rotation.

Although various studies have found social influence to positively affect adoption (Katungi, 2006; Mashavave et al., 2013; Yaméogo, William, Fonta, \& Wünscher, 2018) the study found mixed, but not statistically significant relationships between social influence and adoption of CA principles. The findings are supported by Talukder and Quazi (2011) and Hulst and Posthumus (2016), who found no social influence or peer pressure effects on adoption. The lack of social influence on adoption in this study could be due to the availability of extension 
services from both public and NGOs as shown in Table 1. During focus group discussions, farmers emphasised the importance and value of the training provided by extension staff in convincing them to practice CA. The findings may also suggest that the communities value expert knowledge more than peers (Bell \& Ruhanen, 2016) or may be due to technology complexity (Kiptot. Franzel, Hebinck \&Richards, 2006. However, the difference in social influence between the two districts could mean that Choma farmers are more likely to learn from their peers than those Nkayi due to the consultative and trusting nature of the communities. Isham (2000) found consultative norms to have a positive effect on adoption. This could suggest that extension approaches that promote peer learning are more likely to succeed in Choma than Nkayi.

\subsection{The Role of Institutional Factors in Adoption (PBC):}

The positive relationship between $\mathrm{PBC}$ and crop rotation means that institutional support was not viewed as essential for the practice of crop rotation. This could be because farmers were able to rotate with traditionally grown legumes, such as cowpeas and groundnuts in their area. The findings are in contrast with reports that suggest that access to legume markets is crucial for the practice of crop rotation (Wall, 2007; Mazvimavi, Twomlow, Belder \& Hove, 2008). The findings could suggest that access to institutional factors such as extension services can help farmers adopt crop rotation. Focus group discussions revealed that extension agents encouraged farmers to use locally available legume crops and trained farmers on how to incorporate legumes into the CA permanent planting station. In previous studies, failure to incorporate legumes into the permanent planting stations in CA was cited as a challenge in the adoption of crop rotation (Mazvimavi et al., 2008).

The negative effects of PBC on minimum soil disturbance indicate a perceived need for institutional support to enable farmers to practice this principle. In Choma, farmers were sharing rippers provided by the project whilst in Nkayi, although hand-hoes were readily available, farmers lamented the need for labour-saving equipment. The principle of minimum soil disturbance is generally viewed as labour-intensive especially where herbicides are not used as this results in high weed pressure (Baudron et al., 2007; Wall, 2007) while for hand-hoe based planting basins it takes more time than ox-ploughing ( Giller et al., 2009). The study also revealed low access to credit by CA farmers, which could have contributed to the perceived need for institutional support for the practice of minimum soil disturbance.

Effects of social system and PBC on area under CA: The positive relationship between social influence and the area allocated to CA could be due to labour pooling activities where farmers worked together to prepare CA rip lines and planting basins (Nyanga, 2012), which may have motivated each member to copy the area under CA from their peers. The positive relationship between area under CA and PBC suggest that farmers did not perceive the need for institutional support to practice CA on large areas. It was, however expected that institutional support in the form of markets and access to implements would be an important factor required to practice CA in large areas. Large farm sizes, availability of labour and more experience with CA could have contributed to these findings in the two districts. Ngwira et al. (2014) found a positive correlation between area allocated to CA and the number of years farmers have practised CA while Arsalan et al. (2013) reported labour availability to be an important determinant of the area allocated to CA.

The negative relationship between customs and the area allocated to CA could be because customs that suspend farm activities delay timely application of CA. CA farmers are expected to be timely in carrying out land preparation, weed management, fertilizer application as part of good management (Twomlow et al., 2008) and tend to abandon CA if they are not able to implement their activities on time (author's personal experience with farmers). These challenges could have contributed to a negative relationship with area under CA.

\section{Conclusion and Recommendations}

The study contributes to literature on CA adoption by specifically addressing the gaps on the attitudes and perceived influence of the social system and institutional environment on the uptake of CA principles. We find differing attitudes towards CA among farmers based on the CA options that were promoted in that particular context. We find that the practice of each of the three CA principles depends on whether the principle in question fits or can be adapted into the social system and institutional setting. Minimum soil disturbance and soil cover were negatively correlated with the institutional environment and social system by-laws respectively. The principle of soil cover provides a shift into the social system as it involves completely new ways of farming compared to traditional methods. Minimum soil disturbance provides a shift in the way land is tilled and requires specific equipment for its practice. It is not clear though why there is a negative relationship between by-laws and crop rotation. We did not find a significant role of customs in the uptake of CA although the relationship with all CA principles was negative. This implies that customs have the potential to have a negative impact on the uptake of CA. We conclude that the inclusion and involvement of custodians of local laws and customs in the 
promotion of $\mathrm{CA}$ is necessary to facilitate the uptake of CA. Institutional support to facilitate access to implements for MSD and improving credit lines targeted for smallholder farmers should be prioritised. Our study did not find a significant role of social influence on the adoption of CA. Further, in depth analysis of conditions necessary for social learning needs to be explored.

Our regression analysis for the effects of the social system and institutional factors on the area under CA had both positive and negative relationships. Social influence positively correlates with area under CA whilst customs have a negative correlation with area under CA. The study also found that CA farmers did not perceive the need for institutional support in determining the area under CA. The findings imply that social influence plays an important role on the area under CA and that access to institutional support is not necessarily an important determinant of the area allocated to CA. The study also implies that although customs do not necessarily influence the actual adoption of CA, they may have negative implications on the area put to CA.

\section{Acknowledgements}

Appreciation goes to the Canadian Food Grains Bank, United Church of Canada and Mennonite Central Committee for the support rendered in working with these two projects.

\section{References}

Ajzen, I., \& Fishbein, M. (1980). Understanding attitudes and predicting social behaviour. Englewood Cliffs, Prentice-Hall.

Ajzen, I. (1991). The theory of planned behaviour. Organizational Behaviour and Human Decision Processes, 50(2), 179-1211. https://doi.org/10.1016/0749-5978(91)90020-T

Anderson, J. A., \& D'Souza, S. (2014). From adoption claims to understanding farmers and contexts: A literature review of conservation agriculture adoption among smallholder farmers in southern Africa. Agriculture, Ecosystems and Environment, 187, 116-132. http://dx.doi.org/10.1016/j.agee.2013.08.008

Arsalan, A., McCarthy, N., Leslie, L., Asfaw, S., \& Cattaneo, A. (2013). Adoption and adoption intensity of conservation agriculture practices in Zambia. ESA working paper no 13-01. Rome, Food and Agriculture Organisation. Retrieved from http://www.fao.org/3/a-aq288e.pdf

Baudron, F., Mwanza, H. M., Triomphe, B., \& Bwalya, M. (2007). Conservation agriculture in Zambia: A case study of southern province. Nairobi. African Conservation Tillage Network, Centre de Coopération Internationale de Recherche Agronomique pour le Développement, Rome, Food and Agriculture Organisation.

Bell, C., \& Ruhanen, L. (2016). The diffusion and adoption of eco-innovation among tourism businesses, the role of the social system. Tourism, Recreation, Research, 41(3), 291-301. https://doi.org/10.1080/02508281.2016.1207881

Corbeels, M., Graaff, J. D., Ndah, T. H., Penot, E., Baudron, F., Naudina, K., \& Adolwa, I. S. (2014). Understanding the impact and adoption of conservation agriculture in Africa: A multi-scale analysis. Agriculture, Ecosystems and Environment, 187, 155-170. https://dx.doi.org/10.1016/j.agee.2013.10.011

Cronbach, L. J. (1951). Coefficient alpha and the internal structure of tests. Psychometrika, 16(3), 297-334. https://doi.org/10.1007/BF02310555

De Winter, J. C. F., \& Dodou, D. (2010). Five-Point Likert Items: T test versus Mann-Whitney-Wilcoxon, Practical Assessment, Research and Evaluation, 15(11), 1-16.

Dube, T., Holman- KeTue, S., Van Rooyen, A., \& Rodrguez, D. (2014). Crop and livestock production for improved food security and livelihoods in rural Zimbabwe. Socioeconomics discussion paper. Series number 29. Retrieved from https://cgspace.cgiar.org/bitstream/handle/10568/56935/ISEDPS_29.pdf?sequence=3

Elaine, A. I., \& Seaman, C. (2007). Likert Scales and Data Analyses. Quality Progress, 40(7), 64-65.

FAO, (2006). Fertilizer use by crop in Zimbabwe. Rome, Food and Agriculture Organization.

FAO, (2010). Farming for the future in Southern Africa: An introduction to conservation agriculture. Technical Brief No 1. Regional Emergency Office for Southern Africa, Food and Agriculture Organisation.

Feder, G., Just, R. E., \& Ziberman, D. (1985). Adoption of agricultural innovations in developing countries: A survey: Economic Development and Cultural Change, 33(2), 255-298. http://dx.doi.org/10.1086/451461

Fishbein, M., \& Ajzen, I. (2010). Predicting and changing behaviour: The reasoned action approach. New York, 
Taylor \& Francis Group. https://doi.org/10.4324/9780203838020

Giller, K. E., Witter, E., Corbeels, M., \& Tittonell, P. (2009). Conservation agriculture and smallholder farming in Africa: The heretics view. Field Crops Research, 114(1), 23-34. https://doi.org/10.1016/j.fcr.2009.06.017

Giller, K. E., Corbeels, M., Nyamangara, J., Triomphe, B., Affholder, F., Scope, 1. E., \& Tittonell, P. (2011). A research agenda to explore the role of conservation agriculture in African smallholder farming systems. Field Crops Research, 124(3), 468-474. https://doi.org/10.1016/j.fcr.2011.04.010

Hulst, V. F. J., \& Posthumus, H. (2016). Understanding (non-) adoption of conservation agriculture in Kenya using the reasoned action approach, Land Use Policy, 56, 303-314.

http://dx.doi.org/10.1016/j.landusepol.2016.03.002

Isham, J. (2000). The effect of social capital on technology adoption: Evidence from rural Tanzania. Prepared for the Conference on opportunities in Africa: Micro-evidence on firms and households. Centre for the study of African economies. Retrieved from http://citeseerx.ist.psu.edu/viewdoc/download?doi=10.1.1.522.4999\&rep=rep1\&type=pdf

Kassam, A. (2014). Overview of the current status of conservation agriculture globally and challenges of designing and adapting conservation agriculture to the circumstances of the smallholder. In W. H. Vance, R. W. Bell, \& M. E. Haque, (Eds.), Proceedings of the conference on conservation agriculture for smallholder farmers in Asia and Africa (pp. 2-5). Mymensingh, Bangladesh.

Kassam, A., Friedrich, T., \& Derpsch, R. (2018). Global spread of conservation agriculture. International Journal of Environmental Studies. https://doi.org/10.1080/00207233.2018.1494927

Kate, S., Haverkamp, S., Mahmood, F., \& Feldberg, F. (2010). Social network influences on technology acceptance: A matter of tie strength, centrality and density. 23rd Bled eConference eTrust: Implications for the individual, enterprises and society. Bled, Slovenia.

Katungi, E. M. (2006). Social capital and technology adoption on small farms: The case of banana production technology in Uganda. Doctoral dissertation, University of Pretoria, Pretoria, South Africa. Retrieved from https://repository.up.ac.za/bitstream/handle/2263/24679/Complete.pdf?sequence=14

Kiptot, E., Franzel, S., Hebinck, P., \& Richards, P. (2006). Sharing seed and knowledge: Farmer to farmer dissemination of agroforestry technologies in western Kenya. Agroforestry Systems, 68(3), 167-179. https://doi.org/10.1007/s10457-006-9007-8

Knowler, D., \& Bradshaw, B. (2007). Farmers' adoption of conservation agriculture: A review and synthesis of recent research. Food Policy, 32, 25-48. https://doi.org/10.1016/j.foodpol.2006.01.003

Livingston, G., Schonberger, S., \& Delaney, S. (2011). Sub-Saharan Africa: The state of smallholders in agriculture. Conference on new directions for smallholder agriculture. Rome, International Fund for Agriculture Development.

Marongwe, L., Kwazira K., Jenrich, M., Thierfelder, C., Kassam, A., \& Friedrich, T. (2011). An African success: The case of conservation agriculture in Zimbabwe. International Journal of Agriculture Sustainability, 9(1), 153-161. https://doi.org/10.3763/ijas.2010.0556

Mashavave, T., Mapfumo, P., Mtambanegwe, F., Gwandu, T., \& Siziba, S. (2013). Interaction patterns determining improved information and knowledge sharing among smallholder farmers. African Journal of Agricultural and Resource Economics, 8(1), 1-12.

Masikati, P. (2011). Improving water productivity of integrated crop-livestock systems in the semi-arid tropics of Zimbabwe: An ex-ante analysis using simulation modelling (Doctoral dissertation, University of Bonn, Germany). Retrieved from http://hss.ulb.uni-bonn.de/2011/2463/2463.pdf

Mazvimavi, K., Twomlow, S. J., Belder, P., \& Hove, L. (2008). An assessment of the sustainable adoption of conservation farming in Zimbabwe. Global theme on agro ecosystems, Report Number 39. Bulawayo, Zimbabwe, ICRISAT.

Mazvimavi, K., \& Twomlow, S. J. (2009). Socioeconomic and institutional factors influencing adoption of conservation farming by vulnerable households in Zimbabwe. Journal of Agricultural Systems, 101, 20-29. https://doi.org/10.1016/j.agsy.2009.02.002

Ngwira, A., Johansen, F. H., Aune, B., Mekuria, M., \& Thiefelder, C., (2014). Adoption and extent of adoption of conservation agriculture practices among smallholder farmers in Malawi. Journal of Soil and Water Conservation, 69(2), 107-119. https://doi.org/10.2489/jswc.69.2.107 
Nyamangara, J., Nyengerai, K., Masvaya, E. N., Tirivavi, R., Mashingaidze, N., Mupangwa, W., \& Twomlow, S. (2014). Effect of conservation agriculture on maize yield in the semi-arid areas of Zimbabwe. Experimental Agriculture, 50(2), 159-177. https://doi.org/10.1017/S0014479713000562

Nyanga, H. (2012). Factors influencing adoption and area under conservation agriculture: A mixed methods approach. Sustainable Agriculture Research, 1(2), 27-40. https://doi.org/10.5539/sar.v1n2p27

O’Connell, A. A. (2011). Logistic Regression Models for Ordinal Response Variables. Sage Publications, California.

Pannell, D. J., Marshal, G. R., Barr, N., Curtis, A., Vanclay, F., \& Wilkinson, R. (2006). Understanding and promoting adoption of conservation practices by rural landholder. Australian Journal of Experimental Agriculture, 46(11), 1407-1424. http://dx.doi.org/10.1071/EA05037

Pedzisa, T., Rugube, L., Winter-Nelson, A., Baylis, K., \& Mazvimavi, K. (2015). Abandonment of conservation agriculture by smallholder farmers in Zimbabwe. Journal of Sustainable Development, 8(1), 69-82. https://doi.org/10.5539/jsd.v8n1p69

Prager, K., \& Posthumus, H. (2010). Socio-economic factors influencing farmer adoption of soil conservation practices in Europe. In T. L., Napier (Ed.), Human dimensions of Soil and Water conservation (pp. 1-32). Nova Science Publishers.

Rogers, E. M. (1992). Diffusion of innovations (4th ed). New York, Free Press.

Rogers, E.M. (2003). Diffusion of innovations (5th ed). New York, Free Press.

Schmitt, N. (1996). Uses and abuses of coefficient alpha. Psychological Assessment, 8, 350-353. https://doi.org/10.1037/1040-3590.8.4.350

Shaw, A. (1987). Approaches to agriculture technology adoption in the third world: a critical review. Geoforum, 18, 1-119. https://doi.org/10.1016/0016-7185(87)90017-0

Shula, R. K., Hamisi, M., Mwanza, H., Mpanda, M., Muriuki, J., \& Mkomwa, S. (2012). Policies and institutional arrangements relevant to conservation agriculture with trees in Zambia. Retrieved from http://outputs.worldagroforestry.org/cgi-bin/koha/opac-detail.pl?biblionumber=34658

Talukder, M., \& Quazi, A. (2011). The impact of social influence on individuals' adoption of innovation. Journal of Organizational Computing and Electronic Commerce, 21(2), 111-135. http://dx.doi.org/10.1080/10919392.2011.564483

Twomlow, S. J., Urolov, J, C., Jenrich, M., \& Oldrieve, B. (2008). Lessons from the field - Zimbabwe's conservation agriculture task force. Journal of SAT Agricultural Research, 6, 1-10.

Vincent, V., \& Thomas, R. G. (1960). An agro ecological survey of southern Rhodesia: Part 1-Agro-ecological survey. Salisbury, Rhodesia, Government printers.

Wall, P. C. (2007). Tailoring conservation agriculture to the needs of small farmers in developing countries. Journal of Crop Improvement, 19(1-2), 137-155. https://doi.org/10.1300/J411v19n01_07

Yaméogo, H. P., William, M., Fonta, W. M., \& Wünscher, T. (2018). Can social capital influence smallholder farmers' climate-change adaptation decisions? Evidence from three semi-arid communities in Burkina Faso, west Africa. Social Sciences, 7(3), 1-20. https://doi.org/10.3390/socsci7030033

Zimbabwe Vulnerability Assessment Committee (ZimVac) (2013). Zimbabwe Vulnerability Assessment Committee, Rural Livelihoods Assessment. Harare, Zimbabwe.

\section{Notes}

Note 1 . USD $=10$ Zambian Kwacha at the time of the study.

Note 2. Zimbabwe was officially using the USD at the time of the survey.

\section{Copyrights}

Copyright for this article is retained by the author(s), with first publication rights granted to the journal.

This is an open-access article distributed under the terms and conditions of the Creative Commons Attribution license (http://creativecommons.org/licenses/by/3.0/). 